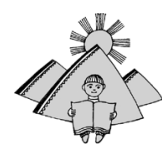

doi: $10.15330 /$ msuc.2019.20.19-27
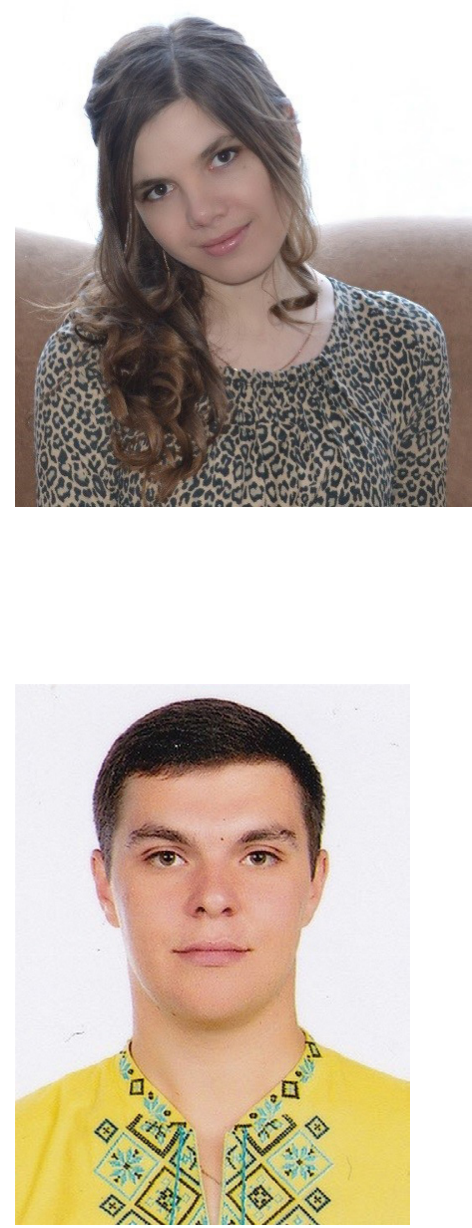

Леся Хрущ,

кандидат економічних наук, доцент кафедри методики навчання математики та інформатики, ДВНЗ «Прикарпатський національний університет імені Василя Стефаника»

(м. Івано-Франківськ, Україна)

\section{Lesya Khrushch,}

Ph. D (Economic Sciences), Associate Professor, Department of Mathematics and Informatics and Methods of Teaching, Vasyl Stefanyk Precarpathian National University (Ivano-Frankivsk, Ukraine) Lessja2501@gmail.com, ORCID 0000-0002-8559-8712

\section{Василь Лотоцький,}

магістрант, ДВНЗ «Прикарпатський національний університет імені Василя Стефаника» (м. Івано-Франківськ, Україна)

\section{Vasyl Lototskyi,}

Graduate student, Vasyl Stefanyk Precarpathian National University (Ivano-Frankivsk, Ukraine) lototskyi_vasyl@comp-sc.if.ua ORCID 0000-0002-9987-2110

\title{
ЗАСТОСУВАННЯ ПРОГРАМИ GEОGЕВRА ДЛЯ ОРГАНІЗАЦІї НАВЧАЛЬНО-ПІЗНАВАЛЬНОЇ ДІЯЛЬНОСТІ УЧНЯ
}

Анотація. У статті узагальнено досвід використання можливостей інструментів програмного засобу GeoGebra як системи активізації навчально-пізнавальної діяльності учнів у процесі навчання математики. Важливим завданням шкільної освіти $€$ подання логічно структурованого матеріалу з елементами графічного представлення для швидкого сприйняття та опрацювання учнями необхідної інформації, тому, безперечно, в процесі навчання математичних дисциплін доцільно використовувати окремі компоненти комп'ютерно-орієнтованої системи навчання для розвитку проектнодослідницької діяльності учнів. У роботі проаналізовано функціональні можливості системи динамічної математики з точки зору інноваційності та перспектив її використання в освітньому процесі. Розглянуто можливість організації емпіричного дослідження властивостей математичних об'єктів. Створено групи класів задач, при розв'язуванні яких доцільно використовувати програмний засіб автоматизації побудов та обчислень GeoGebra. Наведено окремі приклади застосування програм динамічного математичного моделювання до різного типу завдань та методичні особливості використання інтерактивного математичного середовища. Проаналізовано, що в процесі навчання математики система GeoGebra використовується як засіб для візуалізації досліджуваних математичних об'єктів, виразів, ілюстрації методів побудови; як середовище для моделювання та «математичного експерименту» для виявлення властивостей досліджуваних об'єктів; як інструментально-обчислювальний комплекс. Підтверджено важливість впровадження теорії розв'язування дослідницьких задач з використанням інформаційно-комунікаційних технологій, що сприятиме зацікавленню учнів процесом навчання, розвитку дослідницької діяльності школярів, підвищенню їх розумової активності та надаватиме учневі набір спеціалізованих інструментів для створення і перетворення об'єктів, а також вимірювання необхідних його параметрів.

Ключові слова: система динамічної математики, GeoGebra, математика, інновації, методика, інтерактивні комп'ютерні моделі. 


\title{
APPLICATION OF THE GEOGEBRA PROGRAM FOR THE ORGANIZATION OF EDUCATIONAL AND COGNITIVE PUPIL'S ACTIVITIES
}

\begin{abstract}
The article summarizes the experience of using GeoGebra software tools as a system for activating educational and cognitive activity of pupils in the process of learning mathematics. An important task of school education is the presentation of logically structured material with some elements of graphical representation for quick perception and processing of the necessary information, therefore, of course, in the process of teaching mathematical disciplines it is expedient to use separate components of a computer-oriented learning system for the development of project and research activities of pupils. In this research work functional capabilities of the system of dynamic mathematics from the point of view of innovation and prospects of its use in the educational process are analyzed. The possibility of organizing an empirical study of the properties of mathematical objects is considered. Different groups of problems are created, solving which it is advisable to use the software for automation of constructions and computing GeoGebra. Some examples are given on application of dynamic mathematical modeling programs to different types of tasks and methodical peculiarities of using an interactive mathematical environment. It is analyzed that, in the process of learning mathematics, system GeoGebra is used as the mean for visualization of the studied mathematical objects, expressions, depicting methods of construction; as an environment for modeling and "mathematical experiment" to identify the properties of the objects under reseach; as an instrumental computing complex.

The importance of implementation of solving research problems theory with the use of information and communication technologies is confirmed, this will promote a pupils' interest in the process of learning, the development of pupils'research activities, increase their mental activity and will provide the student with a set of specialized tools for creating and transforming objects, as well as measuring the required parameters.
\end{abstract}

Keywords: system of dynamic mathematics, GeoGebra, Maths, innovations, methodology, interactive computer models.

\section{ВСТУП}

Постановка проблеми. В умовах сучасної національної системи освіти зростає роль інформаційно-комунікаційних технологій. Одним із перспективних напрямів інформатизації шкільної математичної освіти $€$ використання в навчальному процесі програмних засобів навчання, зокрема систем динамічної математики і програм для роботи 3 графіками функцій, геометричними фігурами.

Важливим завданням шкільної освіти є подання логічно структурованого матеріалу з елементами графічного представлення для швидкого сприйняття та опрацювання учнями необхідної інформації.

Саме візуалізація навчальної інформації, комп'ютерне моделювання досліджуваних об'єктів, організація «математичного експерименту» для аналізу та дослідження математичних закономірностей чи властивостей об'єктів має велике значення для сприйняття та засвоєння учнями нового матеріалу. Безперечно, в процесі навчання математичних дисциплін доцільно використовувати окремі компоненти комп'ютерно-орієнтованої системи навчання для розвитку проектно-дослідницької діяльності учнів.

Аналіз останніх досліджень і публікацій. Упровадження IKT в процес вивчення математики в Україні активно розпочалося ще з середини 90-х років минулого століття.

Науковець М. Жалдак (Жалдак М. І., 2011) наголошує, що можна виділити два типи педагогічних програмних засобів (ППЗ): ППЗ, розраховані на зменшення часу спілкування учня і вчителя або й на навчання зовсім без вчителя, та ППЗ, розраховані на якомога інтенсивніше спілкування учнів і вчителя за рахунок ефективного використання засобів IKT і звільнення учнів від необхідності витрачати значний час на виконання технічних, рутинних операцій, коли вони практично не спілкуються з учителем. Вивільнений час міг би бути використаний на постановку проблем, з'ясування разом з учителем сутності досліджуваних процесів і явищ, розробку відповідних інформаційних моделей, встановлення причинно-наслідкових зв'язків і закономірностей, порівняння різноманітних проявів закономірностей, їх аналіз і синтез узагальнюючих висновків, абстрагування від окремих несуттєвих фактів та ознак тощо. Це має важливе значення як для фундаменталізації знань, так і для надання результатам навчання прикладного, практично значущого характеру.

Для супроводу навчального матеріалу можна ефективно використовувати інструментальні засоби, такі, як GRAN1, GRAN-2D, GRAN-3D, DG, Advanced Grapher та KmPlot. Проте з багатьох причин використання цих програм у загальноосвітніх навчальних закладах не набуло системного характеру.

Автори Ю. Горошко та Є. Вінниченко (Горошко Ю. В., \& Вінниченко Є. Ф., 2008) для розв'язування задач $з$ параметрами застосовують програму GRAN-1, що сприяє полегшенню засвоєнню матеріалу.

Науковці Л.Грамбовська, О. Яковчук (Грамбовська Л. В., \& Яковчук О. М., 2010) зазначають, що динамічні моделі об'єктів, створених у середовищі ППЗ GRAN 2D, є потужними засобами освоєння геометричної дійсності, вдало доповнюють арсенал традиційних засобів навчання математики, геометрії. Учені (Смалько О.А., 2003; Вінниченко Є.Ф., \& Костюченко А.О., 2007) досліджують особливості геометричних перетворень у програмі GRAN2D та можливості використання цього програмного засобу на уроках планіметрії .

У посібнику «Математика з комп'ютером» (Жалдак М. І., Горошко Ю. В., \& Вінниченко Є. Ф., 2009) розглянуто різні можливості використання комп'ютера для супроводу навчання математики в середніх навчальних закладах. Також дослідники (Кушнір В. А., \& Ріжняк Р. Я., 2009; Ракута В.М., 2010) аналізують, як можна використовувати комп'ютерне моделювання для дослідження математичних функцій, для роботи з функціями та графіками. Автори посібника «Відкриття геометрії через комп'ютерні експерименти в пакеті DG» (Раков С. А., Горох В. П., \& Осенков К. O та ін., 2002) розглядається вивчення геометрії в пакеті DG.

Важливе місце серед IKT посідають мобільні навчальні середовища. В. Биков (Биков В. Ю., 2008), зокрема, зазначає, що, надаючи певні «свободи» учням, учителям, організаторам освіти щодо здійснення ними навчальної та організаційної діяльності, системи відкритої освіти водночас є системами керованими, створення і використання 
яких підпорядковане цілям освіти на певних етапах їі розвитку. Відкрите навчальне середовище лише допомагає реалізувати основні принципи відкритої освіти.

\section{МЕТА І ЗАВДАННЯ ДОСЛІДЖЕННЯ.}

Дослідження системи GeoGebra як засобу для створення динамічних моделей при вивченні задач 3 параметрами та розробка основних шляхів реалізації цієї програми у навчанні учнів загальноосвітніх шкіл.

МЕтОДИ ДОслІДЖЕНня: під час роботи над публікацією використовувалися методи теоретичного аналізу, синтезу та узагальнення положень означеної проблеми.

\section{РЕЗУЛЬТАТИ ДОСЛІДЖЕННЯ}

Створення інформаційного навчального середовища, яке б відповідало новим вимогам якості освіти, зберігало традиційні методи навчання та використовувало нові прогресивні методи, є важливою складовою організації навчальної діяльності учнів.

Серед існуючих математичних пакетів важливе місце посідає безкоштовна програма GeoGebra. Програма написана Маркусом Хохенвартером мовою Java, працює у великій кількості операційних систем. Перекладена на 39 мов. Програма багатопрофільна. Вона може будувати графіки функцій та плоскі фігури на полотні 2D, об'ємні фігури та їх комбінації на полотні 3D та розв'язувати достатньо широкий клас задач. Вагомим аргументом щодо впровадження системи GeoGebra в процес навчання математики є вільнопоширюваність програмного продукту.

Програма GeoGebra може використовуватися як засіб візуалізації досліджуваних математичних об'єктів, функцій, виразів, ілюстрації побудови розв'язків; може виступати середовищем для моделювання та дослідження властивостей математичних об'єктів; використовуватися як інструментально-вимірювальний комплекс, що надає користувачеві набір спеціалізованих інструментів для створення і перетворення об'єкта, а також вимірювання його заданих параметрів.

Використання системи GeoGebra сприяє візуалізації об'єкта дослідження, демонстрації його властивостей, уникненню рутинних дій, пов'язаних із створенням допоміжних зображень; оформленню навчального матеріалу ілюстраціями (статичними і динамічними зображеннями, графіками, схемами, таблицями), у тому числі різного педагогічного призначення (для формування інтересу учнів до теми пропонованого заняття, візуального супроводу або пояснення виконуваних виразів, демонстрації прикладів застосування здобутих знань у житті) (Гриб'юк О. \& Юнчик В., 2015).

За допомогою GeoGebra можна швидко створювати високоякісні графічні зображення математичних об'єктів (графіки функцій, графіки рівнянь, геометричні фігури, формули, тощо) і потім їх зберігати у файлах графічних форматів (png; svg) або експортувати до буфера обміну.

Виконання на практичних заняттях завдань з математики із використанням середовища GeoGebra сприяє розширенню видів навчальних завдань, включаючи нестандартні завдання експериментального та дослідницького характеру (Гриб'юк О. \& Юнчик В., 2015a; Гриб'юк О. \& Юнчик В., 2015b).

Розв'язування завдань з параметрами дуже часто викликає труднощі в учнів. Нерідко саме такі завдання представлені на олімпіадах різного рівня. У процесі розв'язування задач з параметрами, що містять графічний метод вирішення, виникають дві проблеми: по-перше, правильно та доступно пояснити студенту суть даного методу, по-друге, потрібно вміти правильно відтворити математичну модель задачі за ї̈ умовними зображеннями для різних значень параметра.

Викликати в учня почуття «небоязливості» до завдань з параметрами та їх розуміння є важливим завданням для педагога.

На відміну від інших програм для динамічного маніпулювання математичними об'єктами, ідея GeoGebra полягає в інтерактивному поєднанні геометричного, алгебраїчного і числового моделювання змісту задачі, яке дозволяє організовувати цілеспрямоване спостереження за зміною та взаємозв'язком величин даної задачі, надає можливості для перевірки гіпотез, що виникають при цьому спостереженні, та перевірити їх експериментально.

Однією із значних її переваг є можливість покроково відображати хід побудови фігур. Таким чином, $€$ можливість анімовано змінювати координати точок, тоді фігура ніби оживає на моніторі, змінюючи своє зображення внаслідок зміни координат опорних точок.

Отже, основною особливістю програми GeoGebra $€$ можливість побудови динамічних об'єктів, тобто конструкцій, які змінюються при зміні параметра (параметрів). Такі переваги програмного продукту мають вагоме значення для дослідження розв'язків задач із параметрами.

Завдання з параметрами становлять хоч і невелику, але помітну частину математики. Вони часто бувають дуже складними і вимагають нестандартного підходу до вирішення. Учень, розв'язуючи завдання, може порівняти аналітичні або функціональні методи і перевірити свій результат. Використання графічного методу в цілому часто спрощує і скорочує час вирішення того чи іншого завдання з параметром.

Аналіз у GeoGebra не завжди можливий без математичної суті розв'язання задач. А отже, використання GeoGebra дає можливість підвищити рівень якості розв'язування задач та покращити інформаційну компетентність учня.

Нижче наведено приклади використання системи GeoGebra для розв'язування завдань з параметрами різних типів: дослідження функції на зростання в залежності від параметру, розв'язування ірраціональних рівнянь та ірраціональних нерівностей, які містять параметр. 
Приклади: зростає на R. (Див. Табл.1)

Таблиця 1

Схема розв'язання задачі на дослідження функції на зростання

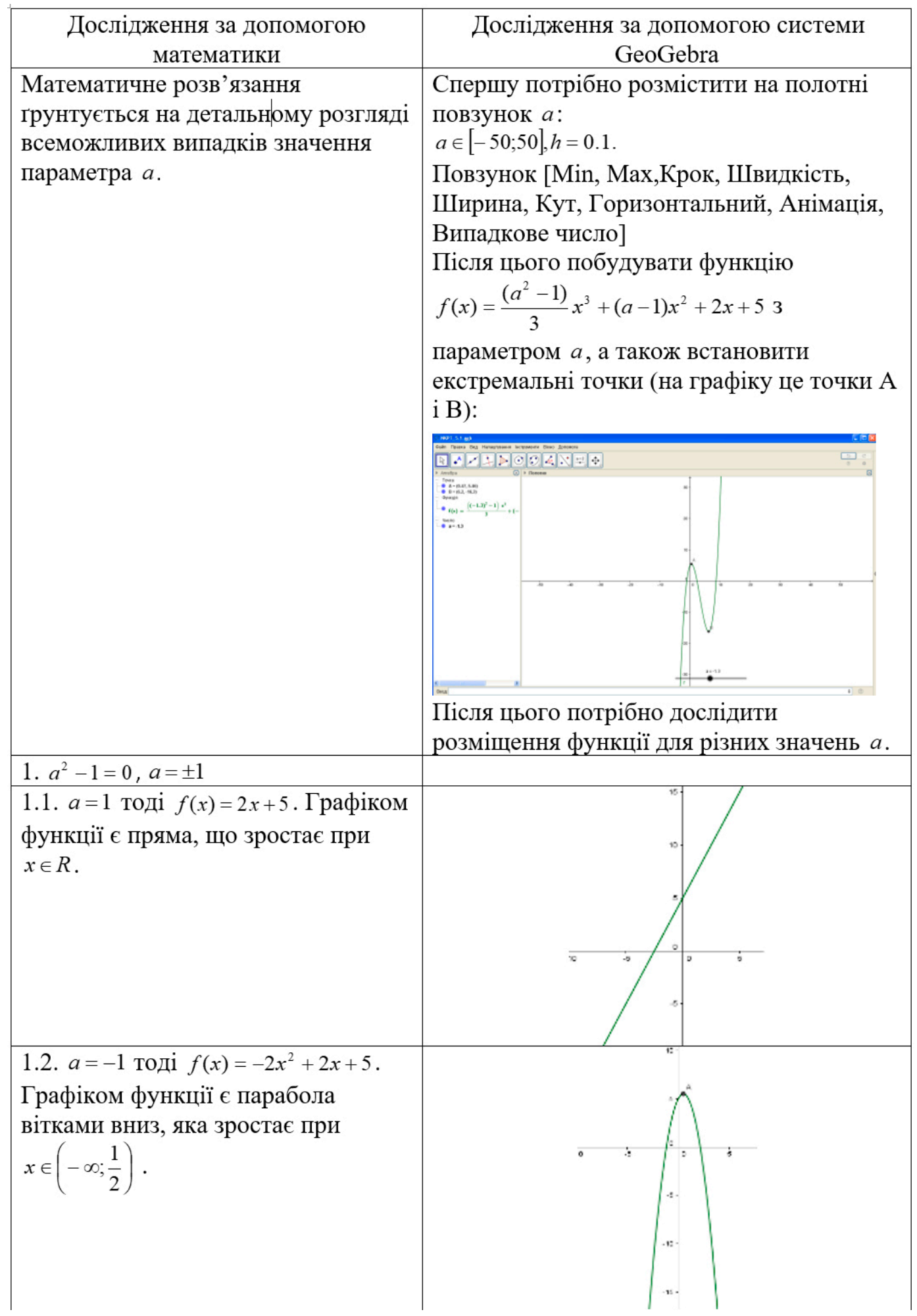


2. $a^{2}-1 \neq 0, a \neq \pm 1$. В цьому випадку дослідження потрібно проводити за допомогою похідної.

$f^{\prime}(x)=\left(a^{2}-1\right) x^{2}+2(a-1) x+2$.

Якщо $f^{\prime}(x)>0$, то функція зростає.

$\left(a^{2}-1\right) x^{2}+2(a-1) x+2=0$

$D=4(a-1)^{2}-8\left(a^{2}-1\right)=$

$=4(a-1)(a-1-2(a+1))=$

$=4(a-1)(-a-3)=-4(a-1)(a+3)$

Знак дискримінанта:

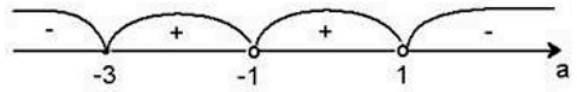

2.1. При $a \in(-3 ;-1) \cup(-1 ; 1)$ знак дискримінанта додатний $(D>0)$. Отже, парабола перетинає вісь $O X$, тоді похідна на цьому проміжку має і додатні і від'ємні значення, отже, функція має проміжки зростання і спадання.

\section{2. При $a \in(-\infty ;-3 ;) \cup(1 ;+\infty)$ знак} дискримінанта від'ємний $(D<0)$. Отже, похідна на цьому проміжку приймає або тільки додатні, або тільки від'ємні значення. Ми розглядаємо випадок, коли на цьому проміжку похідна має додатні значення, адже тоді функція зростатиме.

Знайдемо координати вершини параболи:

$x_{0}=\frac{-2(a-1)}{2(a-1)(a+1)}=\frac{-1}{a+1} ;$

$y_{0}=\frac{\left(a^{2}-1\right)}{(a+1)^{2}}+2(a-1) \cdot \frac{-1}{a+1}+2=$

$=\frac{a-1}{a+1}-\frac{2(a-1)}{a+1}+2=$
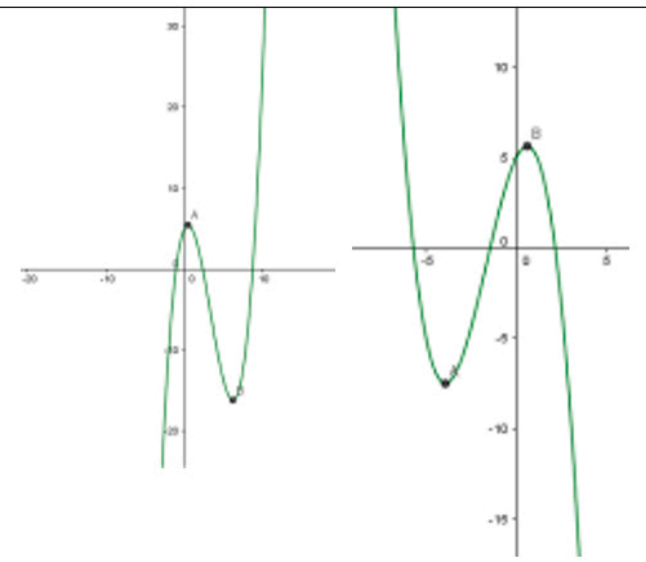

$a \in(-3 ;-1)$

$a \in(-1 ; 1)$

Графіком функції $\epsilon$ квадратна гіпербола, яка має проміжки зростання, спадання та дві екстремальні точки.
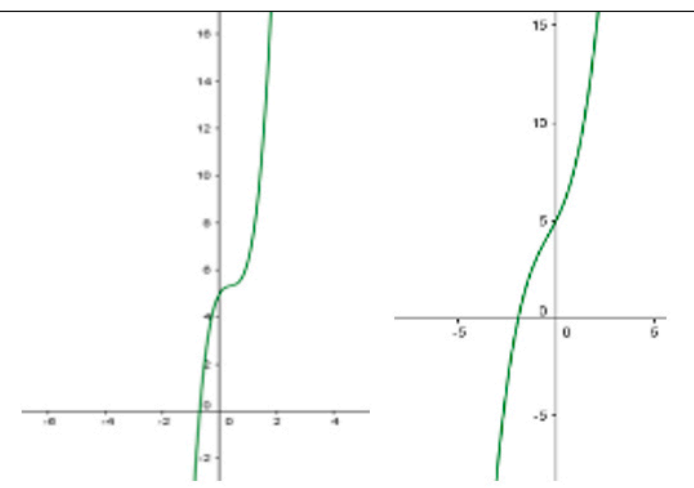

$a \in(-\infty ;-3 ;)$

$$
a \in(1 ;+\infty)
$$

Графік функції зростаюча квадратна гіпербола, екстремальних точок не має. 


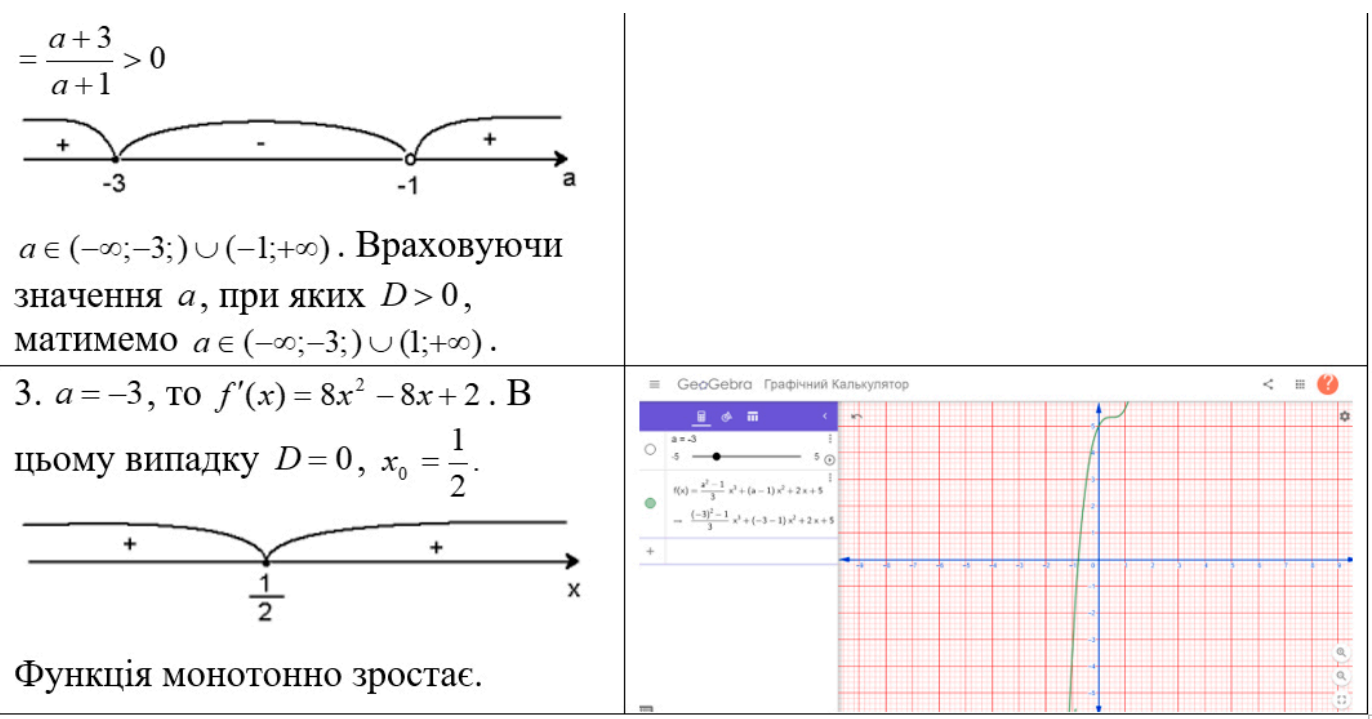

2) Знайти, при якому значенні параметра $a$ відстань між вершинами парабол $y=x^{2}+8 x+5$ та $y=2 x^{2}-8 x+a+2$ є найменшою. (Див. Табл. 2)

Схема розв'язання задачі на дослідження графіків функцій

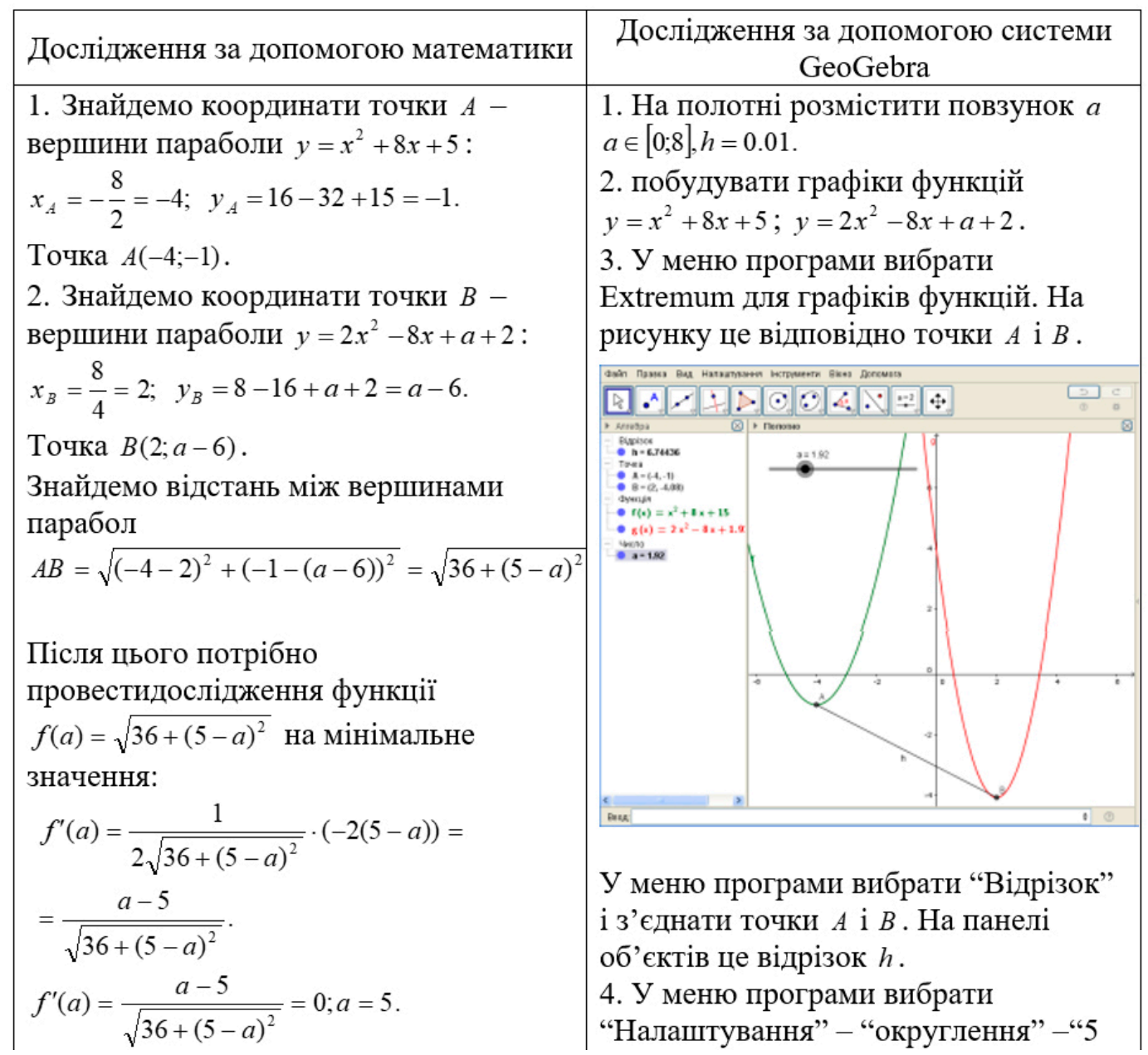




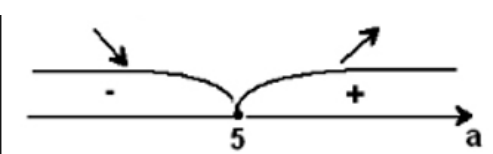

$a=5 €$ точкою локального мінімуму.

Якщо $a=5$, то відстанню між вершинами парабол буде

$A B=\sqrt{36+(5-5)^{2}}=\sqrt{36}=6$. десяткових розрядів".

5. Перемістивши повзунок, знайти найменше значення відстані між вершинами парабол $h=6$ при $a=5$.

3. Знайти всі значення параметра $a$, при яких множиною розв'язків нерівності $\sqrt{1-(x+2 a)^{2}} \geq \frac{4}{3} x$ буде відрізок довжиною $\frac{9}{5}$. (Див. Табл.3)

Схема розв'язання нерівності та аналізу розв'язку

\begin{tabular}{|c|c|}
\hline $\begin{array}{c}\text { Дослідження за допомогою } \\
\text { математики }\end{array}$ & $\begin{array}{c}\text { Дослідження за допомогою системи } \\
\text { GeoGebra }\end{array}$ \\
\hline 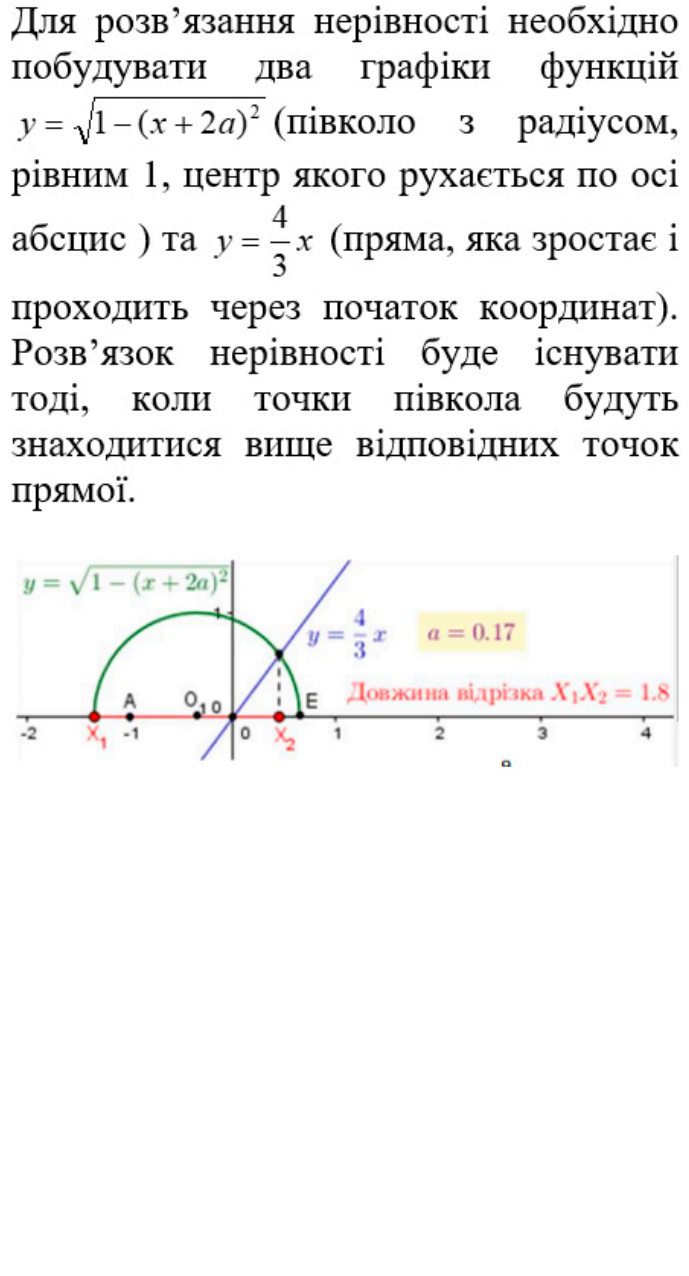 & $\begin{array}{l}\text { На полотні розмістити повзунок } a . \\
\text { Після цього побудувати півколо } \\
y=\sqrt{1-(x+2 a)^{2}} \text { та пряму } y=\frac{4}{3} x \text {. } \\
\text { Знайти точку перетину двох функцій } \\
\text { та перетин функцій з віссю } O X \text { : } \\
\text { Перетин [Об'єкт 1, Об'єкт 2]. } \\
\text { Провести перпендикуляр до осі } O X \text { з } \\
\text { точки перетину двох функцій. } \\
\text { Перпендикулярна пряма [Роінt, } \\
\text { Lіпе]. } \\
\text { Побудувати відрізок } X_{1} X_{2} \text {. } \\
\text { Відрізок [Точка 1, Точка2]. } \\
\text { Знайти довжину відрізка } X_{1} X_{2} \text {. } \\
\text { Відстань [Точка, Об'єкт]. }\end{array}$ \\
\hline
\end{tabular}

Важливим для організації навчальної діяльності є можливість створення груп у середовищі GeoGebra (див. рис. 1.1). Це можуть бути групи поділу на класи, а може бути поділ на книги (розділи) з різними типами завдань (див. рис.1.2). При розподіленні на групи буде зручний доступ та використання саме тих завдань, які потрібно вивчати. 

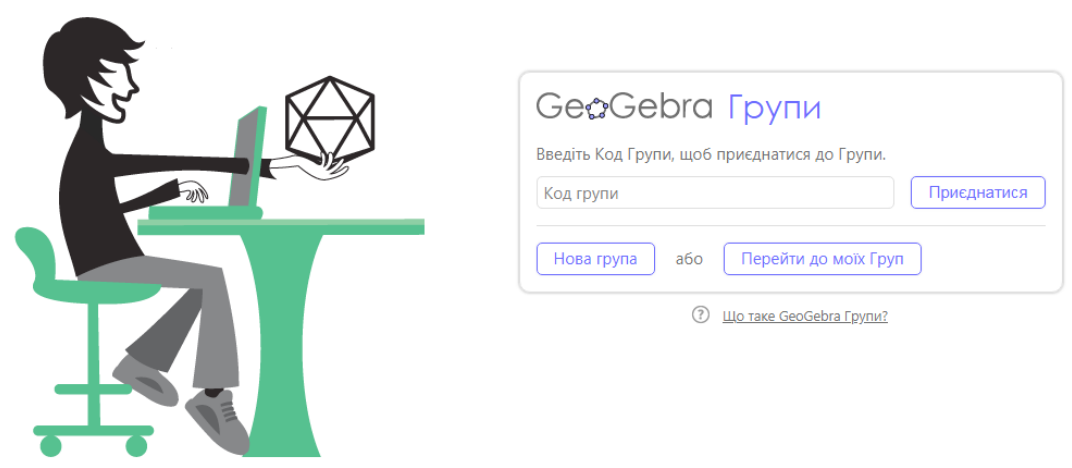

Рис. 1.1. Створення груп у середовищі GeoGebra

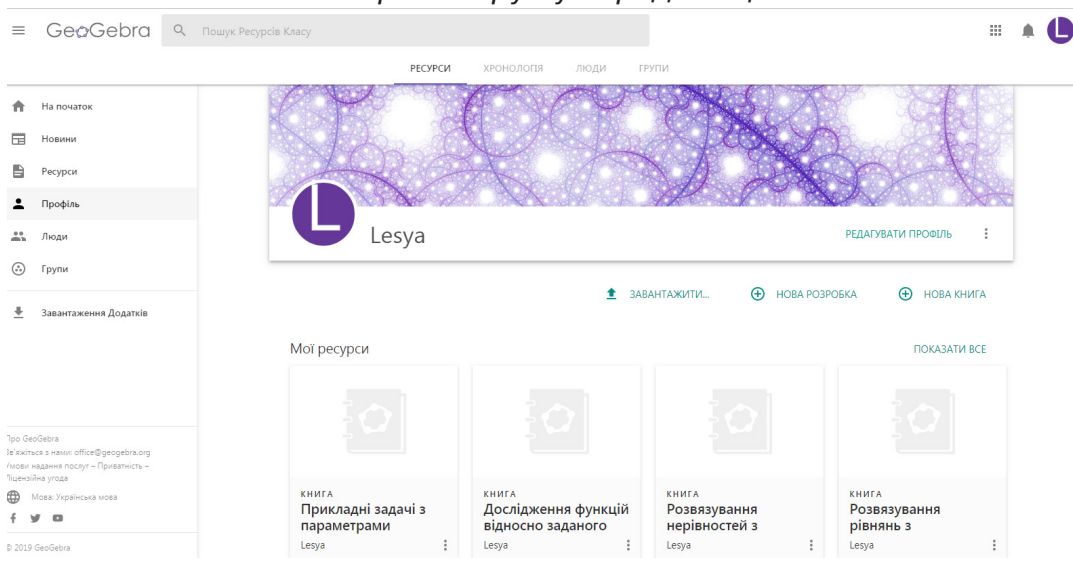

Рис. 1.2. Поділ ресурсів на книги (розділи) з різними типами завдань

Важливо зазначити, що використання програми GeoGebra сприяє формуванню алгоритмічного стилю мислення учнів, наочно демонструються формальний, алгоритмічний характер розв'язування прикладних задач, учні опановують сучасні інформаційно-комунікаційні технології та отримують доступ до структурно впорядкованої навчальної інформації.

\section{ВИСНОВКИ ТА ПЕРСПЕКТИВИ ПОДАЛЬШИХ ДОСЛІДЖЕНЬ}

Процес вирішення математичних завдань, які містять параметр, з використанням комп'ютерно-орієнтованої системи навчання стимулює учнів до розумової активності та сприяє розвитку їхньої проектно-дослідницької діяльності.

Продовження розробки та вдосконалення наявного методичного забезпечення для організації навчальної діяльності учнів з використанням системи динамічної математики GeoGebra сприятиме покращенню ефективності навчання математики, розвитку інформаційної компетентності учнів, зростанню ефективності навчального процесу в загальноосвітньому навчальному закладі в контексті теорії розв'язування задач з параметрами, вдосконаленню методики покрокового аналізу та синтезу розв'язків із використанням пропонованих алгоритмів розв'язування проектно-дослідницьких завдань.

\section{СПИСОК ВИКОРИСТАНИХ ДЖЕРЕЛ}

Жалдак, М. І. (2011). Система підготовки вчителя до використання інформаційно-комунікаційних технологій в навчальному процесі. Науковий часопис НПу імені М. П. Драгоманова. Серія 2: Комп'ютерно-орієнтовані системи навчання, 11, 3-15.

Горошко, Ю. В., \& Вінниченко Є. Ф. (2008). Розв'язування задач з параметрами за допомогою програми «GRAN-1». Математика в школі, 7-8(84). 25-28.

Грамбовська, Л. В., \& Яковчук, О. М. (2010). Комп'ютерні динамічні моделі як засіб дидактичного забезпечення процесу навчання геометрії в сучасній школі. Комп'ютер у школі та сім'ї, 7, 14-17.

Смалько ,O.A. (2003). Використання програмного педагогічного засобу «GRAN-2D» на уроці планіметрії. Математика в школі, 1, $10-14$.

Вінниченко, Є.Ф., \& Костюченко, А.О. (2007). Деякі особливості геометричних перетворень в програмі GRAN-2D. Науковий часопис НПу імені М.П. Драгоманова. Серія № 2. Комп'ютерно-орієнтовані системи навчання : зб. наук. праць. Київ: НПу ім. М.П. Драгоманова, 5(12), 114-120.

Жалдак М. І., Горошко Ю. В., \&Вінниченко Є. Ф. (2009). Математика з комп'ютером : посібник для вчителів. Київ: Вид-во НПУ ім. М. П. Драгоманова. 
Кушнір, В. А., \& Ріжняк, Р. Я. (2009). Технологія дослідження математичних функцій засобами комп'ютерного моделювання. Комп'ютер в школі та сім'ї, 8(78), 12-18.

Ракута, В.М. (2010). Програми для роботи з функціями та графіками. Комп'ютер у школі та сім'ї, 7(87), 29-33.

Раков, С. А., Горох, В. П., \& Осенков, К. О та ін. (2002). Відкриття геометрії через комп'ютерні експерименти в пакеті DG : посібник для викладачів математики. Харків : ХДПУ.

Биков, В. Ю. (2008). Моделі організаційних систем відкритої освіти: Монографія. Київ: Атака.

Гриб'юк, О. \& Юнчик, В. (2015a). Розв'язування евристичних задач в контексті STEM-освіти з використанням системи динамічної математики GeoGebra. Сучасні інформаційні технології та інноваційні методики навчання у підготовці фахівців: методологія, теорія, досвід, проблеми. Зб. наук. пр. 43. Київ-Вінниця: ТОВ фірма «Планер», 206-218.

Гриб'юк, О. \& Юнчик, В. (2015b). Система динамічної математики GeoGebra як засіб активізації дослідницької діяльності учнів. Інформаційно-комунікаційні технологіії в сучасній освіті: досвід, проблеми,перспективи : зб. наук. пр. 4, Is. 1, $163-167$.

Grybyuk, O. O. (2014). Mathematical modelling as a means and method of problem solving in teaching subjects of branches of mathematics, biology and chemistry. Proceedings of the First International conference on Eurasian scientific development. «East West» Association for Advanced Studies and Higher Education GmbH. Vienna, 46-53.

\section{REFERENCES}

Zhaldak, M. (2011). Systema pidgotovky vchytelya do vykorystannya informacijno-komunikacijnyx texnologij v navchalnomu procesi. Naukovyj chasopys NPU imeni M. P. Dragomanova. Seriya 2 : Kompyuterno-oriyentovani systemy navchannya, 11, 3-15.

Goroshko Yu., Goroshko, Yu., \& Vinnychenko, Ye. (2008). Rozvyazuvannya zadach z parametramy za dopomogoyu program«GRAN-1». Matematyka v shkoli, 7-8 (84), 25-28.

Grambovska, L., Yakovchuk, O. (2010). Kompyuterni dynamichni modeli yak zasib dydaktychnogo zabezpechennya procesu navchannya geometriyi v suchasnij shkoli. Kompyuter u shkoli ta simyi, 7, 14-17.

Smalko, O. (2003). Vykorystannya programnogo pedagogichnogo zasobu «GRAN-2D» na uroci planimetriyi. Matematyka v shkoli, 1 , 10-14.

Vinnychenko, Ye. (2007). Deyaki osoblyvosti geometrychnyx peretvoren v programi GRAN-2D. Naukovyj chasopys NPU imeni M.P. Dragomanova. Seriya No2. Kompyuterno-oriyentovani systemy navchannya., NPU im. M.P. Dragomanova, 5(12),114-120.

Zhaldak, M. (2009). Matematyka z kompyuterom: posibnyk dlya vchyteliv. Kyiv: Vydavnycztvo NPU im. M. P. Dragomanova.

Kushnir, V., \& Rizhnyak, R. (2009). Texnologiya doslidzhennya matematychnyx funkcij zasobamy kompyuternogo modelyuvannya (Technology of research of mathematical functions by means of computer modeling). Kompyuter $v$ shkoli ta simyi, 8(78), 12-18.

Rakuta, V. (2010). Programy dlya roboty z funkciyamy ta grafikamy. Kompyuter u shkoli ta simyi, 7(87), 29-33.

Rakov, S., Gorox ,V., \& Osenkov ,K. (2002). Vidkryttya geometriyi cherez kompyuterni eksperymenty v paketi DG : posibnyk dlya vykladachiv matematyky. Kharkiv : XDPU.

Bykov, V. (2008). Modeli organizacijnyx system vidkrytoyi osvity: Monografiya. Kyiv, Ataka.

Grybyuk, O., \& Yunchyk, V. (2015a). Rozvyazuvannya evrystychnyx zadach v konteksti STEM-osvity z vykorystannyam systemy dynamichnoyi matematyky GeoGebra. Modern information technologies and innovation methodologies of education in proffessional training: methodology, theory, experience, problems. Zb. nauk. pr., 43. Kyiv-Vinnycya : TOV firma «Planer», 206-218.

Grybyuk, O., \& Yunchyk, V. (2015b). Systema dynamichnoyi matematyky GeoGebra yak zasib aktyvizaciyi doslidnyczkoyi diyalnosti uchniv. Information and Communication Technology in Modern Education: experience, problems, prospects. Zb. nauk. pr., 4, Is.1,163-167.

Grybyuk, O. O. (2014). Mathematical modelling as a means and method of problem solving in teaching subjects of branches of mathematics, biology and chemistry. Proceedings of the First International conference on Eurasian scientific development. «East West» Association for Advanced Studies and Higher Education GmbH. Vienna, 46-53.

Статтю подано до редколеаії 04.03.2019 p.

Рекомендовано до друку 25.03.2019 р. 